\title{
Suitability of textile dyeing effluents for germinaion and seedling growth of yard long bean
}

\author{
Jahidul Hassan, Mohammad Nazmol Hasan ${ }^{1^{*}}$ and Md. Mijanur Rahman Rajib \\ Department of Horticulture, Bangabandhu Sheikh Mujibur Rahman Agricultural \\ University, Gazipur-1706, Bangladesh
}

\begin{abstract}
Textile Dyeing effluents from seven different stages of dying process were used for irrigation of the pot culture of yard long bean. Maximum germination was found at $6^{\text {th }}$ day of observation and the highest germination rate occurred for treatments with $2^{\text {nd }}$ wash after soaping stage, which was statistically identical with the ground water treatment. Treatment $2^{\text {nd }}$ wash after soaping stage showed the highest germination energy and relative germination rate consequently has the lowest germination injury rate. Treatment $2^{\text {nd }}$ wash after soaping stage also produced the highest shoot length. So the effluent produced from the $2^{\text {nd }}$ wash water after soaping can be used for irrigation of yard long bean.
\end{abstract}

Key words: Textile effluents, germination, seedling growth, yard long bean.

\section{INTRODUCTION}

The economy of Bangladesh is predominantly based on agriculture but, in the race towards industrialization, textile industries are rapidly expanding day by day. There are about 1821 small and large knit dyeing industries in Bangladesh (BKMEA, 2012). The most common textile wet processing setup consists of desizing, scouring, bleaching, mercerizing, dyeing as well as finishing processes. Dyeing is the process of adding color to the fibers, which normally requires a large volume of water. It has been estimated that for dyeing $1 \mathrm{~kg}$ of cotton with reactive dyes requires an average of 70-150L water, dyes, salt, alkalis and others pretreatment and dyeing auxiliaries (Chakraborty et al., 2003). The textile dyeing industries are purring effluent on earth continuously, but if this effluent can be used as irrigation for growing crops will lessen the pressure on ground water and also save our water resource from pollution as the effluent usually drained to river or cannel when it is unused.

Agricultural irrigation with industrial wastewater is a common practice in urban and semi-urban regions of Bangladesh and it is used as a readily available and inexpensive option to fresh water. Addition of such a mixed bag of compounds causes significant shift in the structure and function of a microbial community, which in turn may influence fertility of soil for agriculture. A change in soil microbial diversity or a shift from bacterial to fungal population has also been reported in metal contaminated soils. Oved et

1 Department of Statistics, Bangabandhu Sheikh Mujibur Rahman Agricultural University, Gazipur-1706, Bangladesh.

* Author to whom all correspondences should be made. 
al., 2001 reported that irrigation with wastewater altered ammonia oxidizing bacterial (AOB) population in soil and Nitrosospira and Nitrosomonas species became dominant. Sarnaik \& Kanekar, 1995 reported alteration and reduction in number of Pseudomonas species from soil samples collected from the premises of a dye factory in India. Excess of soluble salts in water result in low crop yields, and if sodium is in excess, soil deterioration occurs as well. Baath (1989) reported that soils with high cation exchange capacity and more organic matter are known to bind metals and make them less available to microorganisms.

Seed germination and plant growth bioassays are the most common techniques used to evaluate phytotoxicity (Kapanen \& Itawara, 2001). The transition from dormancy to germination represents a critical stage in the lifecycle of crop plants, which controls population dynamics and productivity (Keller \& Kollmann, 1999). Moreover, it constitutes an important ecological and commercial trait, (Holdworth et al., 2008). Mohammad \& Khan, 1985 found that industrial effluent reduced the germination percentage of kidney bean (Phaseolus aureus) and ladies' fingers. (Abelmoschus esculentus). While working with Cicer arietinum, Dayama (1987) reported that even highly diluted industrial effluent (5\% of industrial effluent) adversely reduced the seed germination. In contrast, 50\% diluted textile effluent increased the seed germination, total sugars, starch, reducing sugars and chlorophyll of groundnut seedlings (Swaminathan \& Vaidhecswarn, 1991).

Yard long bean is one kind of most popular legume fruit vegetable in our country which is widely cultivated in domestic gardens and farms both in rural and urban areas. Nevertheless, it is also growing in the areas where the effluents are discharged as these crops are preferred to grow with the area of intensive irrigation facilities. Keeping in view the importance of vegetable in human health and adverse effects of textile dying effluents on plant growth, the present study was aimed to assess whether the different stages of textile dyeing effluents could safely be reused to irrigate crop plants through investigating up to what extent heavy metals present in collected textile effluents that affect on the germination percentage as well as their impact on the initial growth of yard long bean seedlings.

\section{MATERIALS AND METHODS}

Collection and characterization of Textile Dyeing Effluents: The textile dyeing effluents of different stages $\left(D_{2}=2^{\text {nd }}\right.$ wash after scouring \& bleaching, $D_{3}=$ Enzyme treatment, $D_{4}=2^{\text {nd }}$ wash after bath, $D_{5}=$ Neutralization treatment, $D_{6}=2^{\text {nd }}$ wash after soaping, $\mathrm{D}_{7}=$ Fixing treatment and $\mathrm{D}_{8}=$ Mixed effluent) were collected in pre-cleaned plastic bottle from Tex Euro Bd. Ltd., Vogra, Gazipur.The effluents were stored at $4^{0} \mathrm{C}$ to avoid changes in their characteristics. Physio-chemical characteristics of textile effluents along with ground water $\left(D_{1}\right)$ were analyzed at the laboratory of DUET, Gazipur, following standard procedure. 
Germination Experiments: The germination test was conducted following the prescribed method in ISTA rules (Anon., 1999) with 480 seeds collected from the Department of Horticulture, BSMRAU, Gazipur. All seeds were surface-sterilized with $1 \%$ sodium hypochlorite $(\mathrm{NaOCl})$ for one minute to prevent any fungal contamination, and thereafter the seeds were washed with distilled water. The Petri dishes and filter papers were sterilized in an autoclave to prevent microbial contamination. Twenty (20) seeds for each treatment were transferred to Petri dishes lined with filter paper (Whatman No. 42). This filter disc was moistened with $4 \mathrm{ml}$ of distilled water as control treatment and with the same quantity of textile effluents. Germination percentage (GP \%), germination energy (GE), relative germination rate (RGR), relative effluent-injury rate (GI) and germination velocity (GV) were determined by the following formula:

Germination percentage $(\mathrm{GP} \%)=\mathrm{a} / \mathrm{b} \times 100$

Germination energy $(\mathrm{GE})=\mathrm{c} / \mathrm{b}$

Relative germination rate $(\mathrm{RGR})=\mathrm{d} / \mathrm{e}$

Relative effluent-injury rate $(\mathrm{GI})=(\mathrm{e}-\mathrm{d}) / \mathrm{e}$

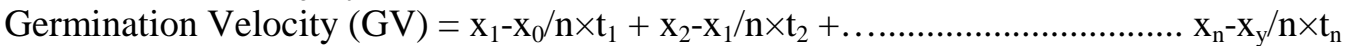

Where, $a$ is the number of germinated seeds, $b$ is total number of seeds used for germination, $\mathrm{c}$ is germinated seeds total in different dyeing effluents in 6 days, $\mathrm{d}$ is germination percentage in effluent treatment and e is germination percentage in control treatment (ground water).

Where, $x$ is the number of seeds germinated per total number of seeds, $n$, emerged on a particular number of day $\mathrm{t}_{1}$ and $\mathrm{x}_{\mathrm{n}}-\mathrm{x}_{\mathrm{y}}$, is the difference between present and last germination, $r$ ranges from $0-1$.

Pot Experiment: Four hundred viable seeds of yard long bean were randomly selected from the stock. 20 seeds were sown in each of twenty four plastic pot $(10 \mathrm{~cm}$ diameter and $10 \mathrm{~cm}$ height) filled with $1 \mathrm{~kg}$ ordinary garden soil washed well first with tap water and then with distilled water so as to flush through all the salts previously present in that soil. The pots were irrigated with under ground water as control treatment and seven different stages of dyeing effluent. For each pot $250 \mathrm{ml}$ of each treatment were applied. This experiment prolonged up to the standard age of transplantation (third leaf stage).

For observing seedling growth at three leaf stage, seedlings were picked from each of the pots and the length of the root, shoot, leaf length, leaf width and fresh weight were recorded at the termination of experiment. Five seedlings were taken for each of the treatment. Then individual plant in separate packet was packed and kept at $70^{\circ} \mathrm{C}$ in an oven for 3 days. Then their dry weights were recorded. The process was replicated for three times and the experiment was laid out following the randomized complete block design (RCBD), then Repeated-Measures Analysis of Variance was used to measure the variation in the effluent effect, time effect and their interaction effect on germination percentage of yard long bean. Mean comparison of different effluent for all the parameters were performed by LSD test at $5 \%$ level of significance. 
Model adequacy checking is the prerequisite to analyze the data for a particular experimental design, interpretation of data based on analysis of variance (ANOVA) is valid only when the assumptions of the particular ANOVA are satisfied. Also the statistical test $\mathrm{t}, \mathrm{F}, \mathrm{z}$ etc. are valid under the assumptions of independence of errors and normality of errors. The departure from these assumptions makes the interpretation invalid. Therefore, it is necessary to detect the deviations and apply the appropriate remedial measures (Parsad \& Bhar, 2012). The model adequacy was checked by Normal probability Plot, Kolmogrov-Smirnov test and Shapiro-Wilks test to test the validity of normality of errors (Parsad \& Bhar, 2012). Bartlett's test was done for the equality of variance for the character under study (Montgomery, 2001).

\section{RESULTS AND DISCUSSION}

Physio-chemical characterization of different stages of textile dying effluents: The physico-chemical characteristics of textile dying effluents of different stages are shown in the Table 1. The $\mathrm{pH}$ of underground irrigation water and textile effluent was within the permissible limits of irrigation water standard except second wash after scouring and bleaching (D2) and mixed effluent from effluents treatment plant (ETP) (D8) (Table 1). Chemical oxygen demand (COD) of the effluent was below irrigation standard while values of other dying effluents were above the standard limit $(400 \mathrm{mg} / \mathrm{l})$, Similar trend was also observed in case of BOD except tube well water (D1). Electrical conductivity exceeded limit as the treatment of second wash after bath drop (BD) (D4) as well as mixed effluent from ETP (D8) than that of standard limit of safe irrigation water (1200 ppm). The similar trend of result was also observed for the chloride content of both the above stated treatment. Except 2nd wash after BD (D4) and Mixed effluent (D8) samples, Dissolve solid was within irrigation standard. Similarly Suspended solid was well above than the irrigation standard in case of (D8). In addition, the other element contents such as sulphate, nitrate, phosphate, lead, copper, nickel, cobalt, chromium and zinc were below the standard limit for irrigation purpose.

Model adequacy check for different germination parameters: The result of model adequacy checking is given in Table 2 . Percentage of germination count on different days after sowing did not meet the assumptions of ANOVA. To make compatible with ANOVA assumptions the square root transformation was done. However, the different characteristics of germination data met the ANOVA assumptions. The compatibility of the ANOVA assumptions was also shown in the normal probability plot Figure 1. 
Table 1. Physio-chemical characterization of textile dying effluents

\begin{tabular}{|c|c|c|c|c|c|c|c|c|c|}
\hline \multirow[t]{2}{*}{ Parameters } & \multirow{2}{*}{ 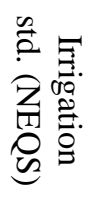 } & \multicolumn{8}{|c|}{ Treatments } \\
\hline & & $\mathrm{D}_{1}$ & $\mathrm{D}_{2}$ & $\mathrm{D}_{3}$ & $\mathrm{D}_{4}$ & $\mathrm{D}_{5}$ & $\mathrm{D}_{6}$ & $\mathrm{D}_{7}$ & $\mathrm{D}_{8}$ \\
\hline $\mathrm{P}^{\mathrm{H}}$ & $6-9$ & 6.8 & 9.4 & 6.3 & 8.8 & 7.1 & 7.4 & 7.3 & 9.5 \\
\hline DO ( mg/l) & $4.5-8$ & 4.1 & 5.85 & 6.12 & 4.58 & 5.0 & 5.80 & 4.77 & 0.19 \\
\hline $\begin{array}{c}\text { Color } \\
\text { (pt.co- unit) }\end{array}$ & 7 & 16 & 97 & 67 & 477 & 367 & 171 & 348 & 1038 \\
\hline TDS(mg/l) & 2100 & 300 & 910 & 650 & 2170 & 1840 & 470 & 1290 & 3320 \\
\hline TSS (mg/l) & 200 & 30 & 40 & 50 & 60 & 60 & 40 & 40 & 310 \\
\hline E.Conductivity & 1200 & 350 & 850 & 900 & 1350 & 550 & 480 & 700 & 4200 \\
\hline BOD (mg/l) & 250 & 57 & 35 & Nil & 411 & Nil & 214 & 350 & 900 \\
\hline COD ( mg/l) & 400 & 310 & 454 & 1374 & 450 & 525 & 630 & 199 & 478 \\
\hline $\begin{array}{l}\text { Nitrate }\left(\mathrm{NO}_{3}{ }^{-}\right) \\
(\mathrm{mg} / \mathrm{l})\end{array}$ & 10 & ND & 0.8 & 0 & 0.6 & 0 & 0.3 & 0.8 & 0.8 \\
\hline $\begin{array}{c}\text { Phosphate } \\
\left(\mathrm{PO}_{4}^{-3}\right) \\
(\mathrm{mg} / \mathrm{l})\end{array}$ & 15 & ND & 0.52 & 0.81 & 0.23 & 0.27 & 0.19 & 1.06 & 0.40 \\
\hline $\begin{array}{c}\text { Sulphate } \\
\left(\mathrm{SO}_{4}^{2--}\right) \\
(\mathrm{mg} / \mathrm{l})\end{array}$ & 1000 & ND & 9.0 & 1.0 & 44 & 0 & 1.0 & 1.0 & 80 \\
\hline $\begin{array}{c}\text { Chloride }\left(\mathrm{Cl}^{-}\right) \\
(\mathrm{mg} / \mathrm{l})\end{array}$ & 1000 & 31 & 08 & 05 & 2500 & 58 & 64 & 42 & 2700 \\
\hline $\begin{array}{l}\text { Copper }(\mathrm{Cu}) \\
(\mathrm{ppm})\end{array}$ & 1.0 & ND & ND & ND & 0.299 & 0.681 & 0.005 & 0.006 & 0.111 \\
\hline $\begin{array}{l}\text { Cobalt(Co) } \\
\text { ppm }\end{array}$ & $\begin{array}{c}\mathrm{NGV} \\
\mathrm{S}\end{array}$ & ND & ND & ND & 0.369 & 0.138 & ND & ND & 0.255 \\
\hline Zinc $(\mathrm{Zn}) \mathrm{ppm}$ & 5 & ND & ND & ND & 0.914 & 0.192 & 0.316 & 0.384 & 0.354 \\
\hline Lead $(\mathrm{Pb}) \mathrm{ppm}$ & 0.5 & ND & ND & ND & 0.0236 & 0.008 & 0.0232 & 0.0192 & 0.0263 \\
\hline Ni ppm & 1.0 & ND & ND & ND & 0.0045 & 0.0027 & 0.0229 & 0.0262 & 0.0237 \\
\hline Cr ppm & 1.0 & ND & ND & ND & 0.0168 & 0.0039 & 0.0326 & 0.0406 & 0.0306 \\
\hline $\mathrm{Cd} \mathrm{ppm}$ & 0.1 & ND & ND & ND & 0.0046 & 0.0008 & 0.0022 & 0.0026 & 0.0078 \\
\hline
\end{tabular}


Table 2. Model Adequacy for different characteristics of germination data

\begin{tabular}{|c|c|c|c|c|c|}
\hline \multirow[b]{2}{*}{ Data mode } & \multirow[b]{2}{*}{ Characteristics } & \multicolumn{2}{|c|}{ Normality test } & \multirow{2}{*}{$\begin{array}{c}\text { Variance } \\
\text { equality test } \\
\begin{array}{c}\text { Bartlett's test } \\
\text { (P-value) }\end{array}\end{array}$} & \multirow[b]{2}{*}{ Decision } \\
\hline & & \begin{tabular}{c}
\multicolumn{2}{c}{ Kolmogorov- } \\
Smirnov (P- \\
value)
\end{tabular} & $\begin{array}{l}\text { Shapiro- } \\
\text { Wilk } \\
\text { (P-value) }\end{array}$ & & \\
\hline \multirow{3}{*}{$\begin{array}{l}\text { Percentage data } \\
\text { (without } \\
\text { transformation) }\end{array}$} & $\begin{array}{l}\text { Residual } \\
\text { (PG2DS) }\end{array}$ & $0.067^{*}$ & 0.108 & $0.046^{* *}$ & \multirow{3}{*}{$\begin{array}{l}\text { Doesn't give } \\
\text { valid } \\
\text { interpretation } \\
\text { of data }\end{array}$} \\
\hline & $\begin{array}{l}\text { Residual } \\
\text { (PG4DS) }\end{array}$ & $0.004^{* * *}$ & $0.098^{*}$ & 0.141 & \\
\hline & $\begin{array}{l}\text { Residual } \\
\text { (PG6DS) }\end{array}$ & $0.042^{* *}$ & 0.502 & 0.779 & \\
\hline \multirow{3}{*}{$\begin{array}{l}\text { Transformed } \\
\text { data (square } \\
\text { root) }\end{array}$} & $\begin{array}{l}\text { Residual } \\
\text { SQRTPG2DS }\end{array}$ & 0.200 & 0.361 & 0.164 & \multirow{7}{*}{$\begin{array}{l}\text { Will give valid } \\
\text { interpretation } \\
\text { of data }\end{array}$} \\
\hline & $\begin{array}{l}\text { Residual } \\
\text { SQRTPG4DS }\end{array}$ & 0.135 & 0.190 & 0.220 & \\
\hline & $\begin{array}{l}\text { Residual } \\
\text { SQRTPG6DS }\end{array}$ & 0.200 & 0.614 & 0.362 & \\
\hline \multirow{4}{*}{$\begin{array}{l}\text { characteristics } \\
\text { of germination }\end{array}$} & Residual for GE & $0.052^{*}$ & 0.502 & 0.779 & \\
\hline & $\begin{array}{l}\text { Residual for } \\
\text { RGR }\end{array}$ & 0.200 & 0.388 & 0.936 & \\
\hline & Residual for GI & $0.052^{*}$ & 0.502 & 0.779 & \\
\hline & $\begin{array}{l}\text { Residual for } \\
\text { GV }\end{array}$ & 0.200 & 0.254 & 0.857 & \\
\hline
\end{tabular}

Note: ${ }^{*}$ statistically significant at $10 \%$ level of significant, ${ }^{* *}$ statistically significant at $5 \%$ level of significant, **** statistically significant at $1 \%$ level of significant.

GE $=$ Germination Energy

RGR=Relative Germination Rate

GI $=$ Germination Injury

$\mathrm{GV}=$ Germination Velocity

Residual for percentage of germination at $2^{\text {nd }}$ day after sowing (PG2DS)

Residual for percentage of germination at $4^{\text {th }}$ day after sowing (PG4DS)

Residual for percentage of germination at $6^{\text {th }}$ day after sowing (PG6DS)

Residual for square root transformed of percentage of germination at $2^{\text {nd }}$ day after sowing SQRTPG2DS

Residual for square root transformed of percentage of germination at $4^{\text {th }}$ day after sowing SQRTPG4DS

Residual for square root transformed of percentage of germination at $6^{\text {th }}$ day after sowing SQRTPG6DS 

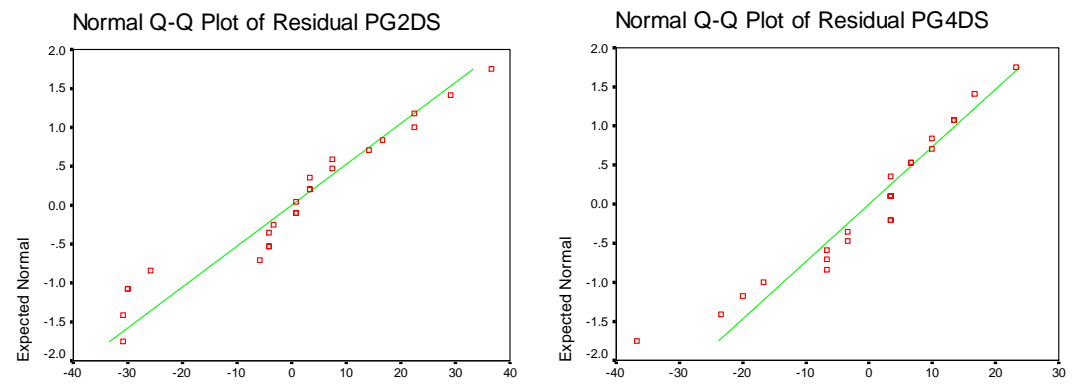

Observed Value

Observed Value
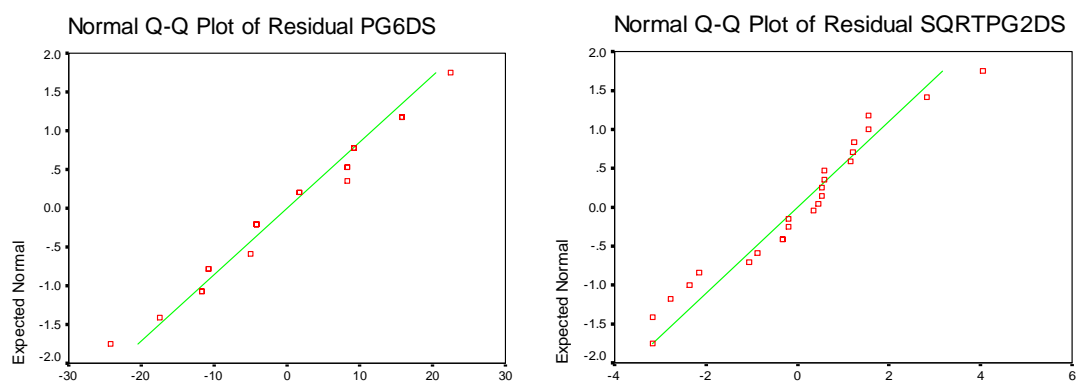

Observed Value

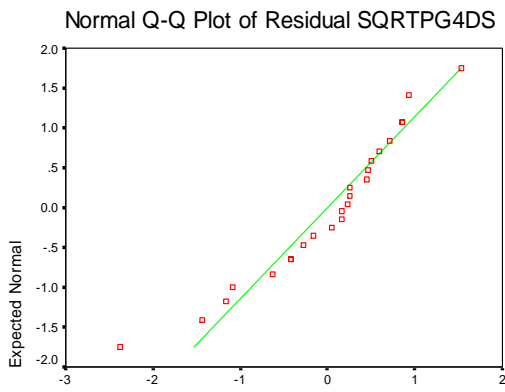

Observed Value

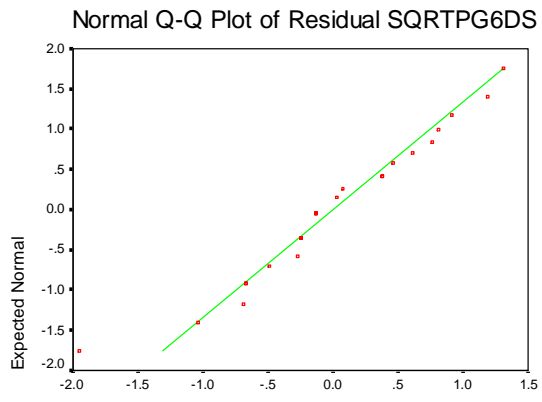

Observed Value

Observed Value

Fig. 1. Normal probability plot of different characteristics of germination data

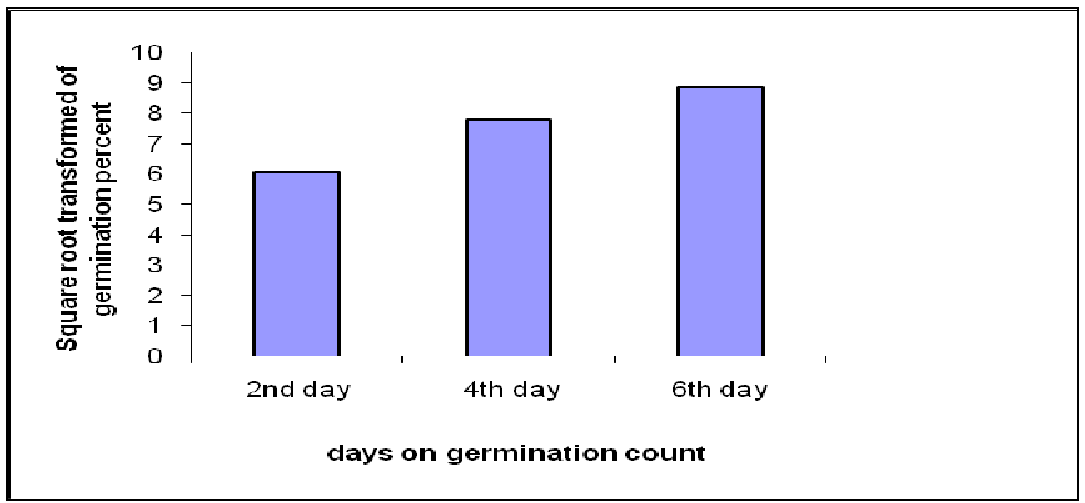

Fig. 2. Square root transformed percentage of germination according to time 
The Repeated-Measures Analysis Variance for measuring the effect of time, textile dyeing effluents and their interaction on germination percentage was used. Time and effluents were found significantly different effect at $1 \%$ and $5 \%$ respectively on germination percentage of yard long bean. Rate of germination over time was significantly different $(\mathrm{P}$-value $=0.000)$ and maximum number of seed germination was observed at $6^{\text {th }}$ day.

According to the Repeated-Measures Analysis Variance, textile dyeing effluent effects on percentage of germination were significantly different $(\mathrm{P}$-value $=0.032)$ at $5 \%$ level of significant. Comparative effect of effluent on germination of yard long bean seeds has been showed in table 3, germination percentage was highest for the treatment of D6, though it was statistically similar with the groundwater treatment (D1). The lowest rate of germination percentage was found for the treatment of D8.

The textile dyeing effluents having significantly different result (Table 3 ) in the case of germination energy $(\mathrm{P}$-value $=0.0446)$, injury $(\mathrm{P}$-value $=0.0446)$ and $\mathrm{GV}(\mathrm{P}$-value $=$ 0.0140). Though all the treatment were given the statistically same result, treatment D6 showed the highest germination energy compare to others and treatment D8 having the lowest germination energy. The lowest germination injury was found in the case of the treatment D6 and the highest germination injury observed for the treatment D8. Comparison among the means of different effluents on germination race was showed in Table 3. The highest germination velocity was observed for the treatment D6, the second highest rate was for the control D1 and the lowest for the treatment D8.

Table 3. Effect of different stages of textile dying effluents on germination attributes

\begin{tabular}{c|c|c|c|c|c}
\hline Treatment & Germination\% & GE \% & RGR \% & GI \% & GV \% \\
\hline D1 & $8.377 \mathrm{a}$ & $86.67 \mathrm{a}$ & $86.67 \mathrm{a}$ & $13.33 \mathrm{~b}$ & $37.22 \mathrm{ab}$ \\
D2 & $7.366 \mathrm{ab}$ & $73.33 \mathrm{a}$ & $73.33 \mathrm{a}$ & $26.67 \mathrm{ab}$ & $30.56 \mathrm{ab}$ \\
D3 & $8.016 \mathrm{ab}$ & $86.67 \mathrm{a}$ & $86.67 \mathrm{a}$ & $13.33 \mathrm{~b}$ & $35.00 \mathrm{ab}$ \\
D4 & $8.361 \mathrm{ab}$ & $86.67 \mathrm{a}$ & $86.67 \mathrm{a}$ & $13.33 \mathrm{~b}$ & $36.67 \mathrm{ab}$ \\
D5 & $6.565 \mathrm{bc}$ & $86.67 \mathrm{a}$ & $86.67 \mathrm{a}$ & $13.33 \mathrm{~b}$ & $29.44 \mathrm{~b}$ \\
D6 & $8.885 \mathrm{a}$ & $93.33 \mathrm{a}$ & $93.33 \mathrm{a}$ & $6.667 \mathrm{~b}$ & $41.11 \mathrm{a}$ \\
D7 & $8.136 \mathrm{ab}$ & $80.00 \mathrm{a}$ & $80.00 \mathrm{a}$ & $20.00 \mathrm{~b}$ & $34.44 \mathrm{ab}$ \\
D8 & $5.030 \mathrm{c}$ & $46.67 \mathrm{~b}$ & $46.67 \mathrm{~b}$ & $53.33 \mathrm{a}$ & $16.11 \mathrm{c}$ \\
\hline CV $(\%)$ & 26.89531 & 18.80 & 17.48 & 75.20 & 20.40 \\
\hline
\end{tabular}

Footnote: $* \mathrm{D}_{1}=$ Ground water, $\mathrm{D} 2=2^{\text {nd }}$ wash after scouring $\&$ bleaching, $\mathrm{D}_{3}=$ Enzyme treatment, $\mathrm{D}_{4}=2^{\text {nd }}$ wash after bath, $D_{5}=$ Neutralization treatment, $D_{6}=2^{\text {nd }}$ wash after soaping, $D_{7}=$ Fixing treatment and $D_{8}=$ Mixed effluent.

Data in a column followed by same letter do not differ significantly ( $\mathrm{p}>0.05)$.

Different textile dyeing effluents did not show significant different effect on the shoot length, root length, leaf length, leaf width, fresh weight and dry weight of yard long bean seedling. But from the Figure 3 it is observed that in the cases of growth parameters treatment D6 showed the highest result. On the other hand the lowest performance is observed for the treatment D8 on growth parameters in most of the cases. The results were in agreement with the findings of Kaushik et al. (2005). 


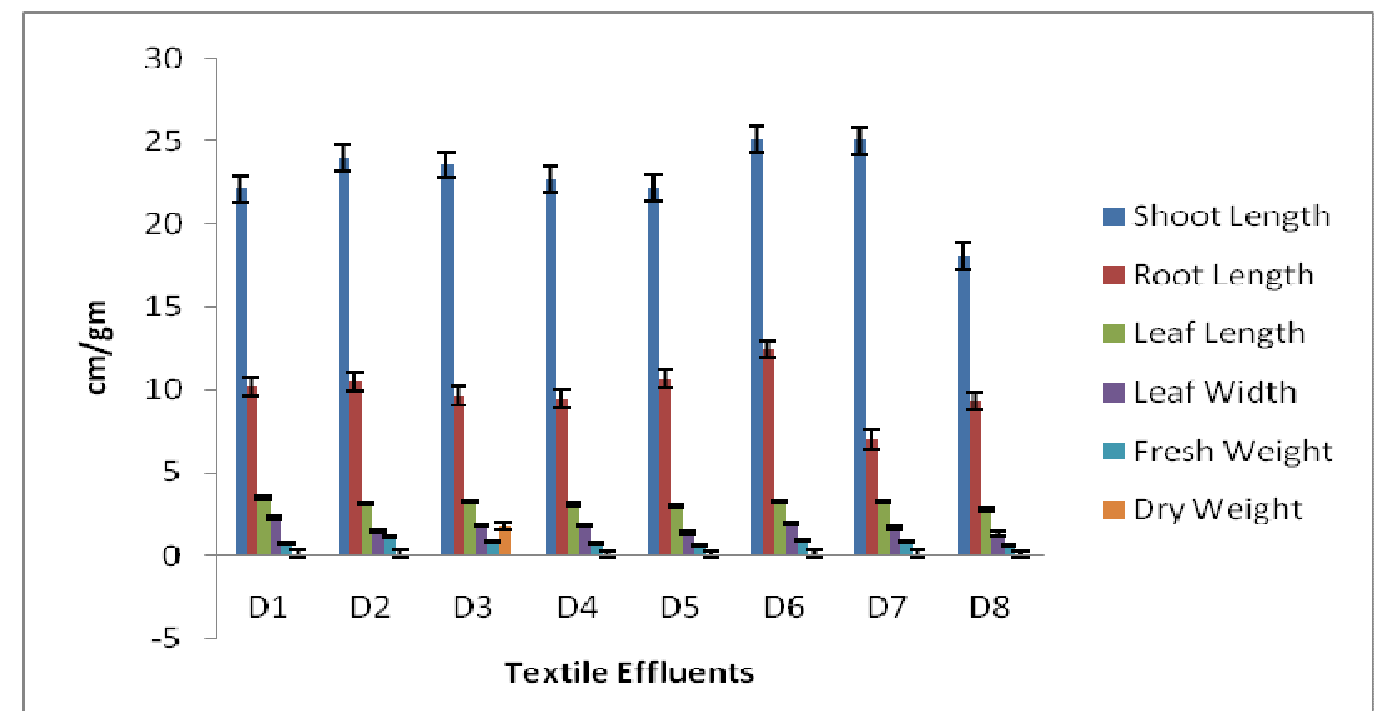

Fig. 3. Effect of textile dyeing effluents on seedling growth parameters of yard long bean

The results of differential germination ability of yard long bean according to the different stages of textile dyeing effluents in the present study is consistent with finding of other workers, e.g., Sesamum indicum (Neelam \& Sahai, 1988) Holchus lanatus (Bradshaw \& McNeilly, 1981) Agrostis stolonifera (Amzallag et al., 1990). The reduction in germination percentage of Turnip in untreated textile effluent might have been due to presence of high concentration of $\mathrm{Ni}^{2+}, \mathrm{Cd}^{2+}$, and $\mathrm{Pb}^{2+}$, and other toxic organic compounds that cause a range of cellular toxicities (Kadar \& Kastori, 2003). Although osmotic potential of the effluent was not recorded, it is also possible that the presence of high amount of salts and organic compounds in D8 stage of textile effluent reduces the availability of water thereby resulting in reduced germination. This aspect is further supported by the fact that presence of high salts in water or soil reduces the germination and early growth of plants by salt-induced osmotic stress that varies from species to species (Ashraf, 2004). Few years back, Ramana et al. (2002) found that the osmotic potential of the textile effluent is higher at higher concentrations, which retards germination of different vegetable crops. Slight reduction in growth of yard long bean was observed at D5 treatment due to due to the presence of some heavy metals. This argument has been further supported by findings of (Srivastava \& Sahai, 1987) who reported that irrigation with textile effluent (distillery effluent have a very low amount of toxic material) reduced the growth Cicer artinum. Overall, this inhibition in growth and germination may have been due to presence of heavy metals such as $\mathrm{Ni}^{2+}$ and $\mathrm{Pb}^{2+}$ that cause toxicity at cellular as well as at the whole plant level (Kadar \& Kastori, 2003). Furthermore, presence of heavy metals in the growth medium also causes reduction in uptake of other essential nutrients thereby resulting in reduced growth. For example, while working with tomato seedlings, Palacios et al. (1998) concluded that presence of elevated concentration of $\mathrm{Ni}$ in rooting medium may cause disturbances and imbalances of different essential mineral elements. 
The wastewater of 2 nd washes water soaping stage (D6) performed well than the other treatments and statistically identical with the ground water treatment (D1). Therefore, the textile dyeing effluents should be discharged after proper dilution that would help the effluent's characteristics to come within the prescribed disposal limits and pollution load per unit effluent volume. Differential germination and growth response of yard long bean was depending on the stages of textile dyeing effluents. Thus it is necessary to study the behavior of individual crops before it is irrigated with textile effluent, which may be an additional source of water having fertilizing properties after proper dilution.

\section{REFERENCES}

Anonymous. 1999. International rules for seed testing. Seed Sci. Tech., 27 : 25-30.

Amzallag, G. N., Lerner H. R. and Poljakoff-Mayber A. 1990. Exogenous ABA as a modulator of the response of sorghum to high salinity. J. Exp. Bot., 41: 1529-1534.

Ashraf, M. 2004. Some important physiological selection criteria for salt tolerance in plants. Flora, 199, 361-376.

Baath, E. 1989. Effects of heavy metals on soil microbial processes and populations (a review). Wat. Air Soil Poll., 47: 335-379.

BKMEA. 2012. Membership profile. Retrieve 12 December, 2012 from www.bkmea.com Bangladesh Knitwear Manufacturers \& Exporters Association

Bradshaw, A. D. and McNeilly, T. 1981. Evolution and pollution. London: Edward Arnold.

Chakraborty.S, M.K.Purkait,S.DasGupta,S.De, and K.Basu. 2003. Nanofillteration of textile plant effluent for color removal and reduction in COD.sep.purif. Technolol 31:141-151.

Dayama, O. P. 1987. Influence of dyeing and textile water pollution on nodulation and germination of gram (Cicer Arietinum). Acta Ecologia, 9(2): 34-37.

Holdworth, M. j. , L. Bentsink and W. J.J. Soppe. 2008. Molecular networks regulating Arabidopsis seed maturation, after-ripening, dormency and germination. Net Phytol., 179:33-54.

Kadar, I. and Kastori, R. 2003. Mikroelem-terhelés hatása a repcére karbonátos csernozjom talajon. Agrokémia és Talajtan, 52: 331-346.

Kapanen, A. and M. Itawara. 2001. Ecotoxicity tests for compost application. Ecotox. Environ. Safety., 49: 1-16.

Kaushik, P., Garg, V. K. and Singh, B. 2005. Effect of textile effluent on growth performance of wheat cultivars. Bioresource Technology, 96: 1189-1193.

Keller, M., and J. Kollmann. 1999. Effects of seed provenance on germination of herbs for agricultural compensation sites. Agric. Ecosyst. Environ., 72: 87-99.

Mohammad, A. and Khan, A. U. 1985. Effect of a textile factory effluent on soil and crop plants. Environmental Pollution, 37: 131-148 Serial A.

Montgomery D C. 2001. Design and analysis of experiments. Retrive from http://www.aliquote.org/articles/tech/dae/dae.pdf. Accessed on March 04, 2013.

Neelam, and Sahai, R. 1988. Effect of textile effluent on seed germination, seedling growth, pigment content and biomass of Sesamum indicum. Linnean Journal of Environmental Biology, 9:45-50.

Oved, T., A. Shaviv, T. Goldrath, R.T. Mandelbaum and D. Minz. 2001. Influence of effluent irrigation on community composition and function of ammonia-oxidizing bacteria in soil. Appl. Environ. Microbiol., 67: 3426-3433. 
Palacios, G., Gomez, I., Carbonell-Barrachina, A., Pedreno, J. N. and Mataix, J. 1998. Effect of nickel concentration on tomato plant nutrition and dry matter yield. Journal of Plant Nutrition, 21:2179-2191.

Parsad R. and Bhar L. M. 2012. Diagnostics and Remedial Measures. Retrieve 12 December, 2012 from http://www.iasri.res.in/ebook/EBADAT/3

Ramana, S., Biswas, A. K., Kundu, S., Saha, J. K. and Yadava, R. B. R. 2002. Effect of distillery effluent on seed germination in some vegetable crops. Bioresource Technology, 82: 273275.

Sarnaik, S. and P. Kanekar. 1995. Bioremediation of color of methyl violet and phenol from a dye industry waste effluent using Pseudomonas sp. isolated from factory soil. J. Appl. Bacteriol. 79: 459-469.

Srivastava, N. and Sahai, R. 1987. Effect of distillery wastewater on the performance of Cicer arietinum L. Environmental Pollution, 43: 91-102.

Swaminathan, K. and Vaidhecswarn, P. 1991. Effect of dying factory effluents on seed germination and seedling development of groundnut (Arachis hypogea). Journal of Environmental Health. 19(3): 165-175 